THE HARRY PANNICK PROSPECT ON FLUME CREEK FAIRBANKS DISTRICT, ALASKA

BY

THEODORE VANCE, MINING ENGINEER

SEPTEMBER 4, 1968

PE 49-20

FAIRBANKS, ALASKA

KX 49285 


\title{
THE HARRY PANNICK PROSPECT ON FLUME CREEK \\ FAIRBANKS DISTRICT, ALASKA
}

\author{
BY
}

THEODORE VANCE, MINING ENGINEER

SEPTEMBER 4, 1968

Mr. Harry Pannick and partner, Al Stevens, have been placer mining for several years on Flume Creek near its confluence with Pedro Creek. During the course of operations, a cut was made to bedrock on the left Jimit bench and a vein of sulphide - bearing quartz exposed. Harry Pannick brought in a sample to the Division of Mines and Minerals and requested an examination of the property.

\section{LOCATION}

Flume Creek is reached by the Steese Highway to a road junction about 3 miles northeast of the Village of Fox (see enclosed map). From this junction, a graded road leads northwesterly one and a half miles to the placer operation.

\section{GEOLOGY}

A vein of quartz five feet wide was sifghtly exposed upon arrival at the property. By means of a bulldozer, this vein was ultimately traced for about 100 feet where it disappears beneath the al luvium on the hill to the north. Strike is $\mathrm{N} 20 \mathrm{~W}$, with a vertical dip.

Mineralization consists of pyrrhotite, pyrite, and very sparse chalcopyrite. Wail rock alteration has produced some sericite which gradualiy diminishes away from the vein.

The country rock is Birch Creek schist which locally consists of quartz mica schist with occasional beds of quartzite (strike $\mathrm{N} 40 \mathrm{~W}$, dip 46 east). A fault zone in the schist is exposed 200 feet east of the access road. This fault is marked by three feet of white gouge containing quartz and schist fragments. No sulphides were visible. A five inch vein with crushed quartz occurs ten feet west of the fault. Strike of both vein and fault is N $10 \mathrm{E}$; dip is apparently vertical.

Samples were taken from the fault on the possibility that this could represent a vein which had been subjected to later moyement. 
the following assays were obtained;

Sample

Location

Ounces Per Ton

Gold oz. Silver oz.

1. Qtz vein at nozzle (grab)

2. West Stringer see map

trace

0.01

trace

0.01

trace

0.01

trace

0.03

see map

see map

trace

0.01

0.02

see map trace

see map $\quad 0.01$

0.02
Weight Per Cent

Copper

Tess than 0.01

Tess than 0.07

less than 0.01

less than 0.01

less than 0.01

less than 0.01

less than 0.03

Accuracy of the atomic absorption examination is $\pm 5 \%$ of the reported value.

\section{CONCLUSIONS AND RECOMMENDATIONS}

As a general rule veins containing pyrrhotjte, in the Fairbanks District, have not been rich in gold or silver. However, this is a rough guide onty and does not rule out the possibility of this vein containing ore shoots in places not yet exposed.

It is recommended that samples be taken in other parts of the vein as it is uncovered during future placer operations.

Respectfully submitted

Theodore Vance

Mining Engineer 


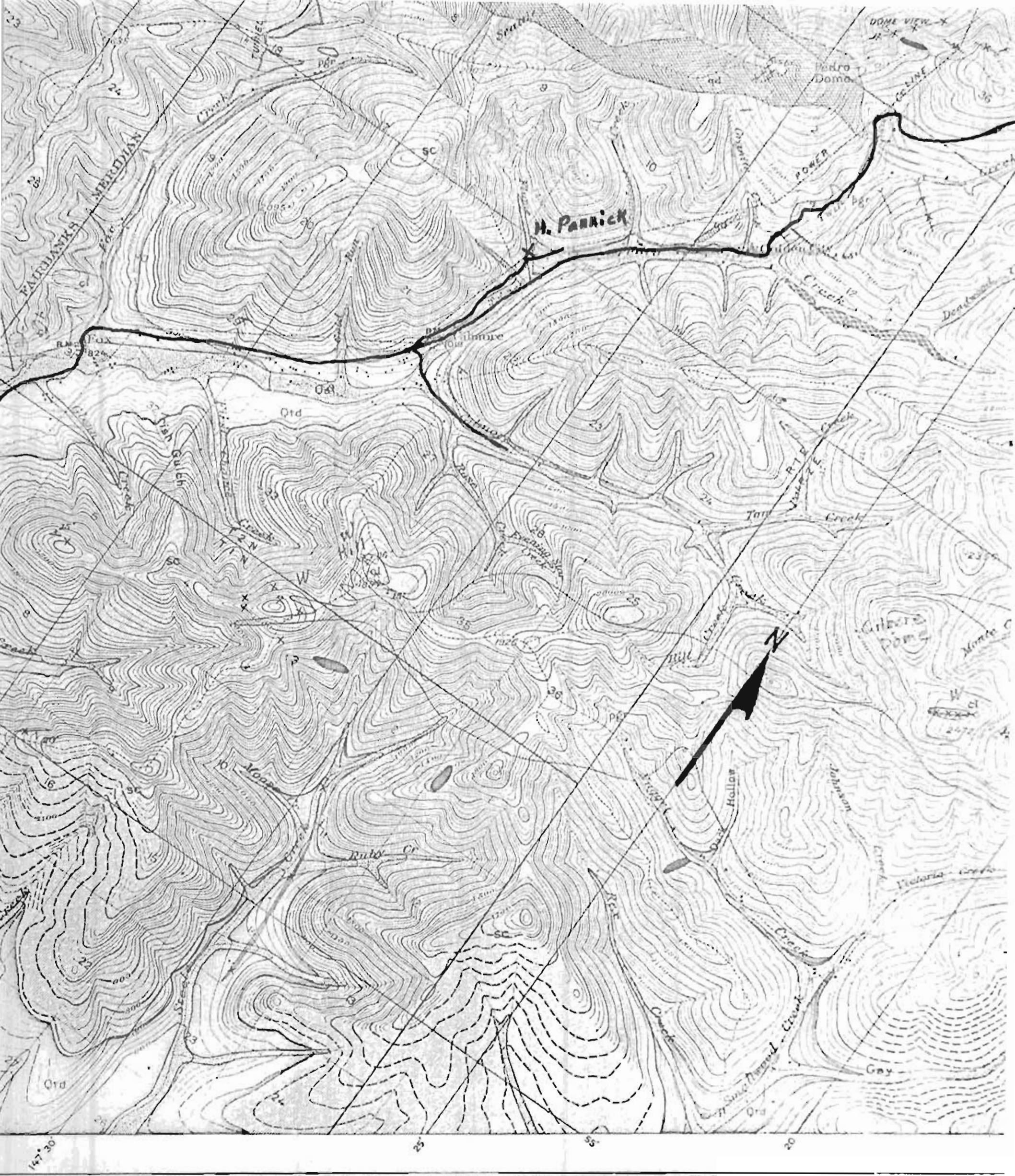

THE FATRBANKS DISTRYCT, ALASKA

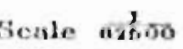




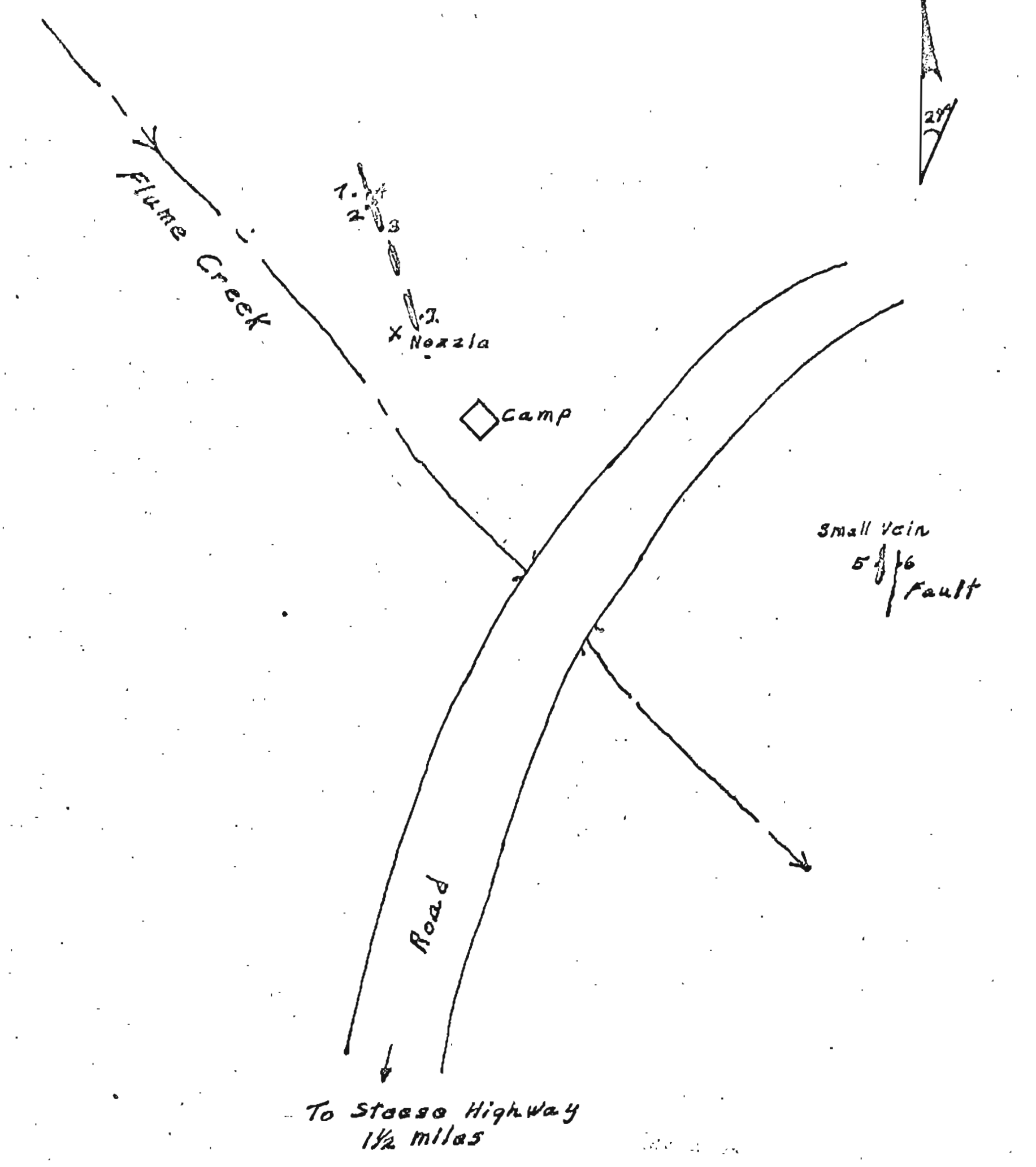

4

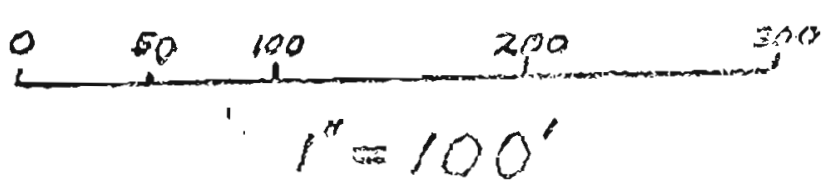

H. Pannick Prospect

$T V$ 